\title{
IMPLEMENTASI MODEL ABC PADA RUMAH SAKIT DENGAN MENGGUNAKAN METODE QFD DAN BENCHMARKING: CONTOH DESAIN
}

\author{
Rini Oktavera \\ Jurusan Teknik Industri, Universitas WR. Supratman Surabaya
}

\begin{abstract}
This research applied quality function deployment method and benchmarking to find out customer needs (a hospital) in term of problems relating with $A B C$ based-cost information system (ABC system) in a hospital. QFD and benchmarking approach was used to yield an $A B C$ model based on technical response which is identified from VOC (voice of customer) analysis. Collected information is not only for determining accurate product cost but it is also useful for operational strategic related with process improvement, product design and performance measurement.

First step is to identify customer needs (a hospital) toward activity based information system (ABC system). Next step is to determine customer needs' priorities based on the collected questionnaire. Best activity is found after constructing matrix of a technical response from a hospital against customer needs. Further step is to do competitor's benchmarking analysis to obtain hospital condition against its competitor. This information will be useful for making an improvement plan toward its own current activity based-information system.

Analysis result shows that customer needs toward ABC model is detail cost information per patient for administration item. Meanwhile, technical response considered by hospital to have high sensitivity toward ABC model is labor cost, special treatment cost, material cost (medicines), laboratory services, material cost for treatment.
\end{abstract}

Key words : Quality Function Deployment, Benchmarking, ABC Systems

\section{PENDAHULUAN}

Isu AFTA 2003 dan globalisasi mengisyaratkan bahwa mekanisme pasar akan semakin didominasi oleh perusahaan atas organisasi bisnis yang mampu memberikan pelayanan atau menghasilkan produk unggulan yang memiliki daya saing tinggi dalam memanfaatkan peluang pasar, keadaan ini berlaku bagi industri perumahsakitan di Indonesia

Pada saat ini permasalahan pokok yang dihadapi oleh Sistem Pelayanan Medik antara lain sebagai berikut:

1. Menurunnya hari-hari rawat sebesar 12,3 persen pada ruang rawat kelas III RSU pemerintah untuk pasien miskin selama dekade terakhir, ini menunjukkan tingkat kepercayaan masyarakat yang menurun di samping ketidakjangkauan pembiayaan, padahal setiap tahunnya total hari rawat meningkat 1 persen.

2. Reformasi sistem pelayanan medik yang berazaz demokrasi, akuntabilitas dan transparansi belum tercapai;

Dari permasalahan tersebut diatas semua berkaitan dengan mutu, efisiensi, keadilan dan pemerataan pelayanan medik. ( Seminar Benchmarking RS, 2000) 
Oleh karena itu diperlukan upaya peningkatan mutu pelayanan kesehatan untuk meningkatkan daya saing usaha Indonesia di sektor kesehatan. Salah satu solusi yang dapat dilakukan pihak manajemen adalah dengan pengimplementasian suatu model analisis untuk pembiayaan kesehatan yaitu model ABC. Karena dengan model analisis ini manajemen rumah sakit dapat mengambil keputusan strategis yang berorientasi jangka panjang misal keputusan terkait dengan penggunaan sumber daya (resources decision) dan keputusan strategis operasional lainnya (misal: perbaikan proses, desain produk dll).

Penelitian yang terkait dengan penggunaan alat-alat manajemen ini dilakukan oleh Katty dan Kidwell (2000). Artikel tersebut mengkaji temuantemuan hasil penelitian $\mathrm{ABC}$, implementasi strategis dan implikasinya terhadap kinerja perusahaan. Penelitian yang dilakukan Swnson (1995) dan Zhuang (1992) menyimpulkan bahwa informasi yang dihasilkan ABC tidak hanya untuk penentuan biaya produk secara akurat, tetapi juga untuk kepentingan strategis operasional, baik menyangkut perbaikan proses, desain produk maupun pengukuran kinerja.

\section{PERUMUSAN MASALAH}

Berdasarkan latar belakang yang telah diuraikan di atas maka permasalahan dalam penelitian ini dapat dirumuskan sebagai berikut:

1. Bagaimana mengidentifikasi atribut konsumen ( kebutuhan rumah sakit dalam sistem pengendalian biaya/ sistem $\mathrm{ABC}$ ) sehingga mengetahui aktivitas-aktivitas apa yang merupakan penentu/ pengendali (cost driver) untuk jasa rumah sakit?

2. Bagaimana mengidentifikasi dan mengetahui respon teknis (model ABC ideal) dari pihak manajemen rumah sakit berdasarkan suara konsumen?

3. Bagaimana mengetahui sistem pembebanan biaya kompetitor lain (rumah sakit) dengan melakukan metode benchmarking?

4. Bagaimana mendesain strategi sistem pembebanan biaya dengan model ABC berdasarkan hasil dari analisa QFD dan Benchmarking?

\section{TUJUAN PENELITIAN}

Tujuan umum dari penelitian ini adalah untuk membantu kebijakan pemerintah tahun 1999 mengenai pencapaian pelayanan prima bagi kesehatan, dengan pengimplementasian model $\mathrm{ABC}$ dalam sistem pembiayaan kesehatan maka pihak RS dapat membuat kebijakan-kebijakan finansial dan nonfinansial yang berorientasi jangka panjang. berikut:

Sedangkan tujuan yang lebih spesifik dari penelitian ini adalah sebagai

1. Mengidentifikasi atribut pemicu/ pengendali biaya yang sesuai dengan kebutuhan konsumen (manajer keuangan rumah sakit) terhadap model ABC dengan menggunakan metode QFD

2. Mengidentifikasi dan menentukan respon teknis (model ABC ideal) dari pihak manajemen rumah sakit berdasarkan suara konsumen. 
3. Membandingkan berbagai sistem pembebanan biaya rumah sakit (kompetitor) lain dengan menggunakan metode benchmarking.

4. Membuat strategi mengenai implementasi dari model ABC.

\section{TINJAUAN PUSTAKA}

\section{Quality Function Deployment (QFD)}

QFD adalah suatu matriks besar yang menghubungkan apa keinginan pelanggan (What) dan bagaimana suatu produk akan didesain dan diproduksi agar memenuhi keinginan pelanggan itu (How). Menurut Thompson dan Chao (1990), QFD adalah metoda analitik dalam mengumpulkan dan menganalisa data subyektif maupun obyektif tentang kebutuhan dan harapan pelanggan. Fokus utama QFD adalah melibatkan konsumen pada proses pengembangan produk sedini mungkin. QFD merupakan praktek untuk merancang suatu proses sebagai tanggapan terhadap kebutuhan konsumen.

Analogi yang sering digunakan untuk menggambarkan struktur QFD adalah suatu matriks yang berbentuk rumah, yang terdiri atas enam tembok atau komponen. Istilah yang digunakan adalah House of Quality (rumah mutu).

Matriks House of Quality (rumah mutu) menurut Cohen (1995) tampak dalam gambar di bawah ini.

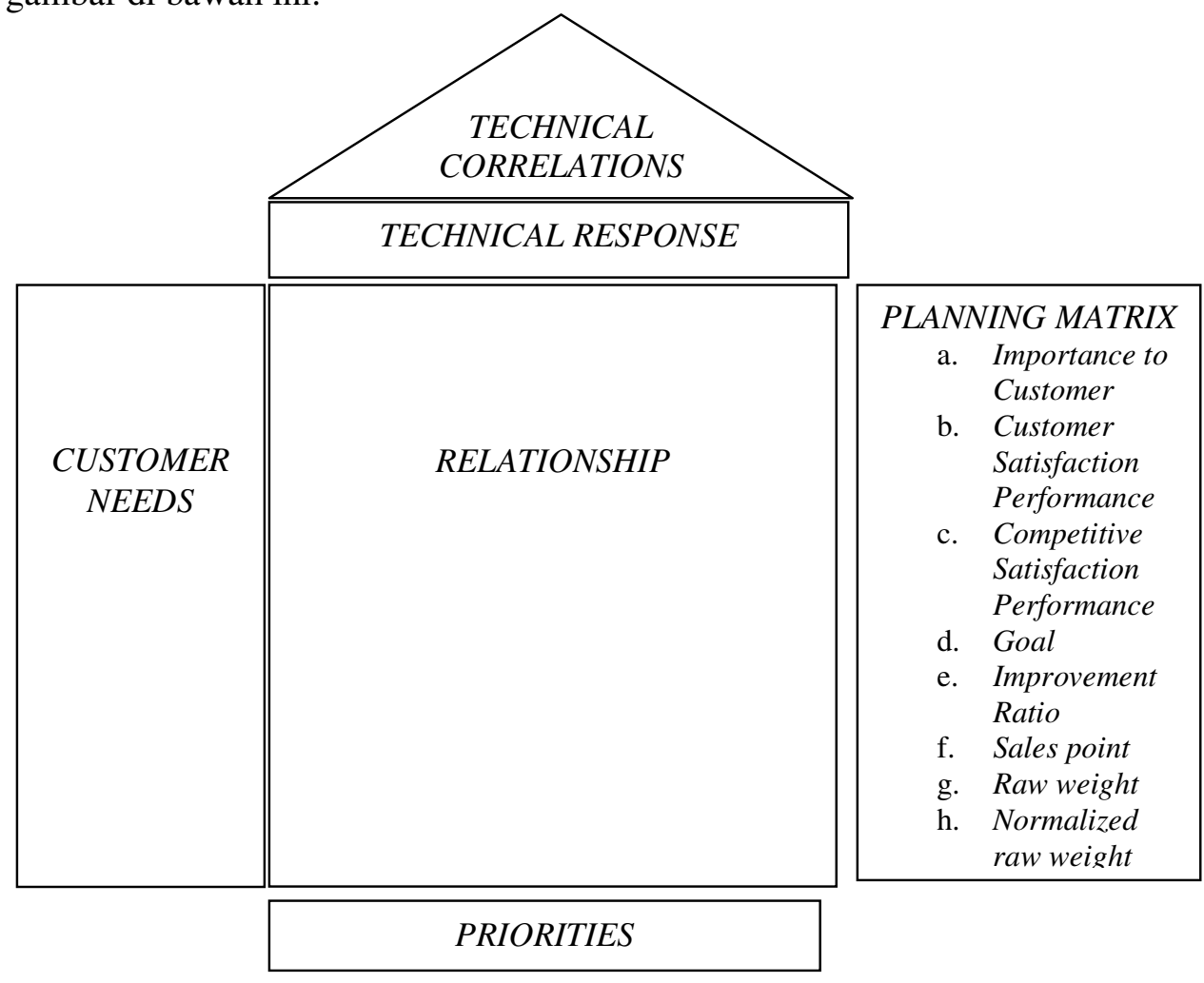

Gambar 1 Struktur Matriks Quality Function Deployment

Langkah-langkah Menyusun House of Quality

Bangunan House of Quality memerlukan enam langkah dasar (Evans dan

Davis dalam Purnama, 2006) yaitu: 
1. Identifikasi atribut-atribut yang dibutuhkan konsumen (customer attributes)

2. Identifikasi ciri-ciri teknis (technical features)

3. Mencari hubungan antara atribut konsumen dengan ciri-ciri teknis

4. Melakukan evaluasi terhadap produk pesaing

5. Melakukan evaluasi terhadap ciri-ciri teknis

6. Menentukan ciri-ciri teknis yang dinilai cocok berdasar atribut-atribut konsumen dan evaluasi produk pesaing untuk disebar (deploy) ke dalam proses produksi.

\section{Benchmarking}

Benchmarking adalah bagian dari manajemen kualitas yang digunakan oleh industri untuk menjadi pemimpin dalam industri tersebut (Camp, 1992). Dengan memperoleh informasi-informasi yang dibutuhkan dalam proses pengembangan yang berkelanjutan maka dapat membantu pengguna metode QFD membuat keputusan strategis dilihat baik dari sisi pemasaran maupun teknis. Penelitian mengenai integrasi kedua metoda itu sudah banyak dilakukan sebagai contoh, Vaziri (1992) menggunakan benchmarking untuk menentukan tujuan dan mencapai kepuasan pelanggan tertinggi.

\section{Activity Based Costing System (ABC System)}

Menurut L. Gayle Rayburn dalam Tunggal (2000), Activity Based Costing (ABC) mengakui bahwa pelaksanaan aktivitas menimbulkan konsumsi sumber daya yang dicatat sebagai biaya. Tujuan Activity Based Costing (ABC) adalah mengalokasikan biaya aktivitas yang dilaksanakan dalam suatu organisasi, kemudian mengalokasikan biaya tersebut secara tepat ke produk atau jasa sesuai dengan pemakaian aktivitas setiap produk atau jasa.

Pada bagan berikut ini sistem ABC digambarkan melalui proses dua tahap yaitu tahap pertama pengidentifikasian dan pengelompokan aktivitas dan tahap kedua adalah pembebanan biaya ke produk melalui penelusuran langsung dan penelusuran penggerak

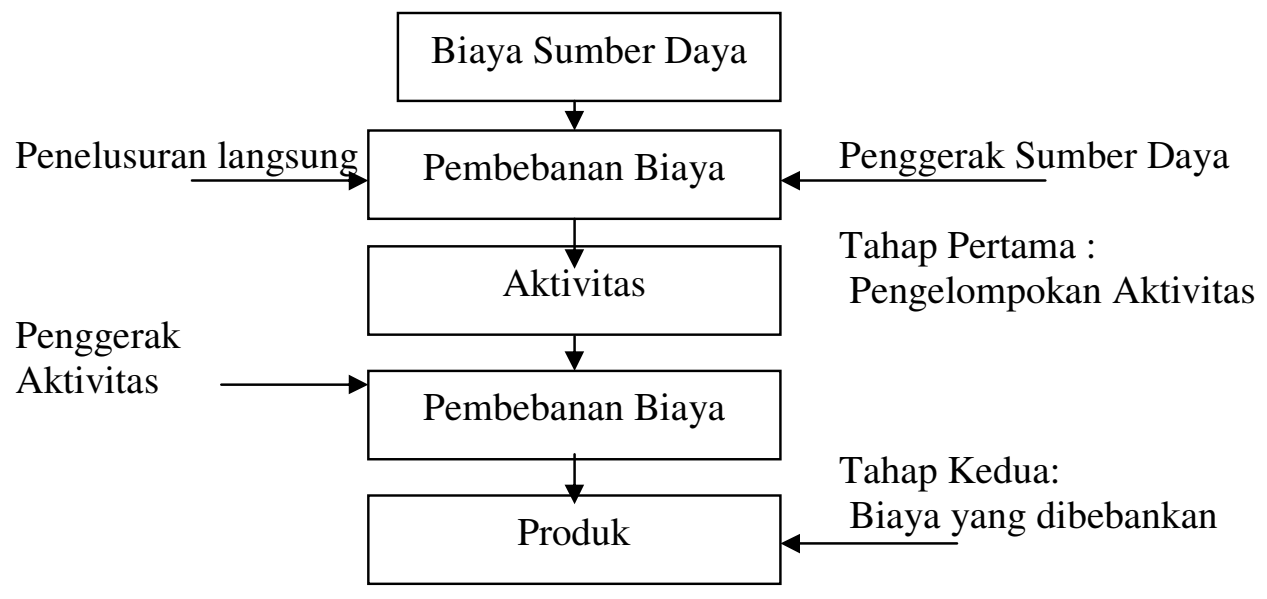

Gambar 2. Kalkulasi Biaya berdasarkan Aktivitas (ABC)

Pada tahap pertama, aktivitas diidentifikasi, biaya-biaya dibebankan kepada aktivitas, aktivitas yang berkaitan digabungkan menjadi satu kelompok, 
kelompok biaya sejenis dibentuk dan tarif kelompok dihitung. Pada tahap kedua, setiap permintaan produk untuk sumber daya kelompok diukur dan biaya-biaya dibebankan kepada produk dengan menggunakan permintaan ini dan tarif kelompok yang mewakilinya.

Beberapa hasil riset menjadi acuan dalam membahas persoalan-persoalan menyangkut implementasi ABC antara lain Magia dan Jacobs (2003) yang mencoba mengkaji interaksi antara $\mathrm{ABC}$ dan BSC terhadap kinerja perusahaan dan mendapatkan kesimpulan interaksi ini mempunyai pengaruh yang positif dengan kinerja. Hal ini berarti bila diimplementasikan secara integratif semakin memberikan peluang terjadinya perbaikan kinerja.

Diagram Alir Penelitian

Tahap Persiapan

Identifikasi dan Perumusan Masalah

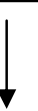

Penentuan Tujuan Penelitian

।
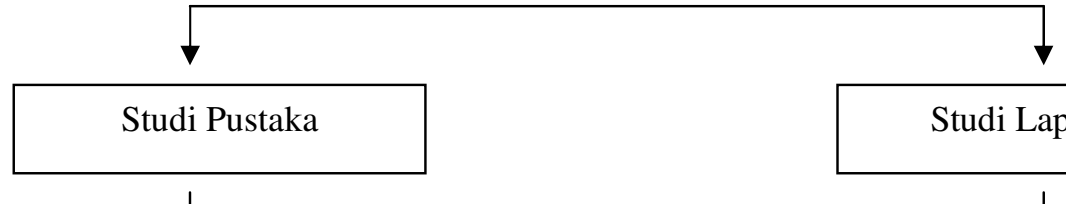

Studi Lapangan

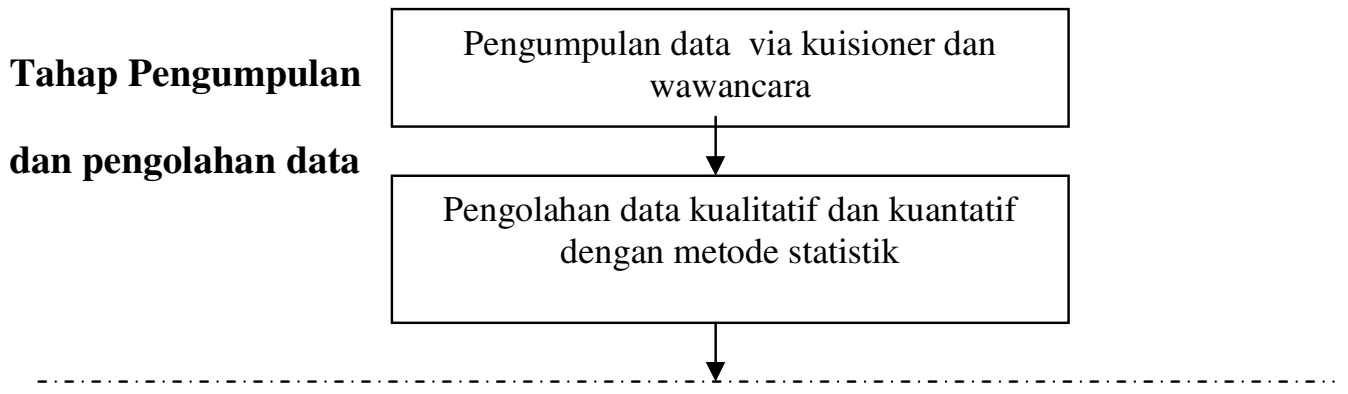

Identifikasi suara konsumen (manajer keuangan RS) thd model ABC

Tahap Pembuatan

HOQ (Rumah Kuali-

Prioritas suara konsumen (VOC)

Respon teknis (model ABC) 
Tas)

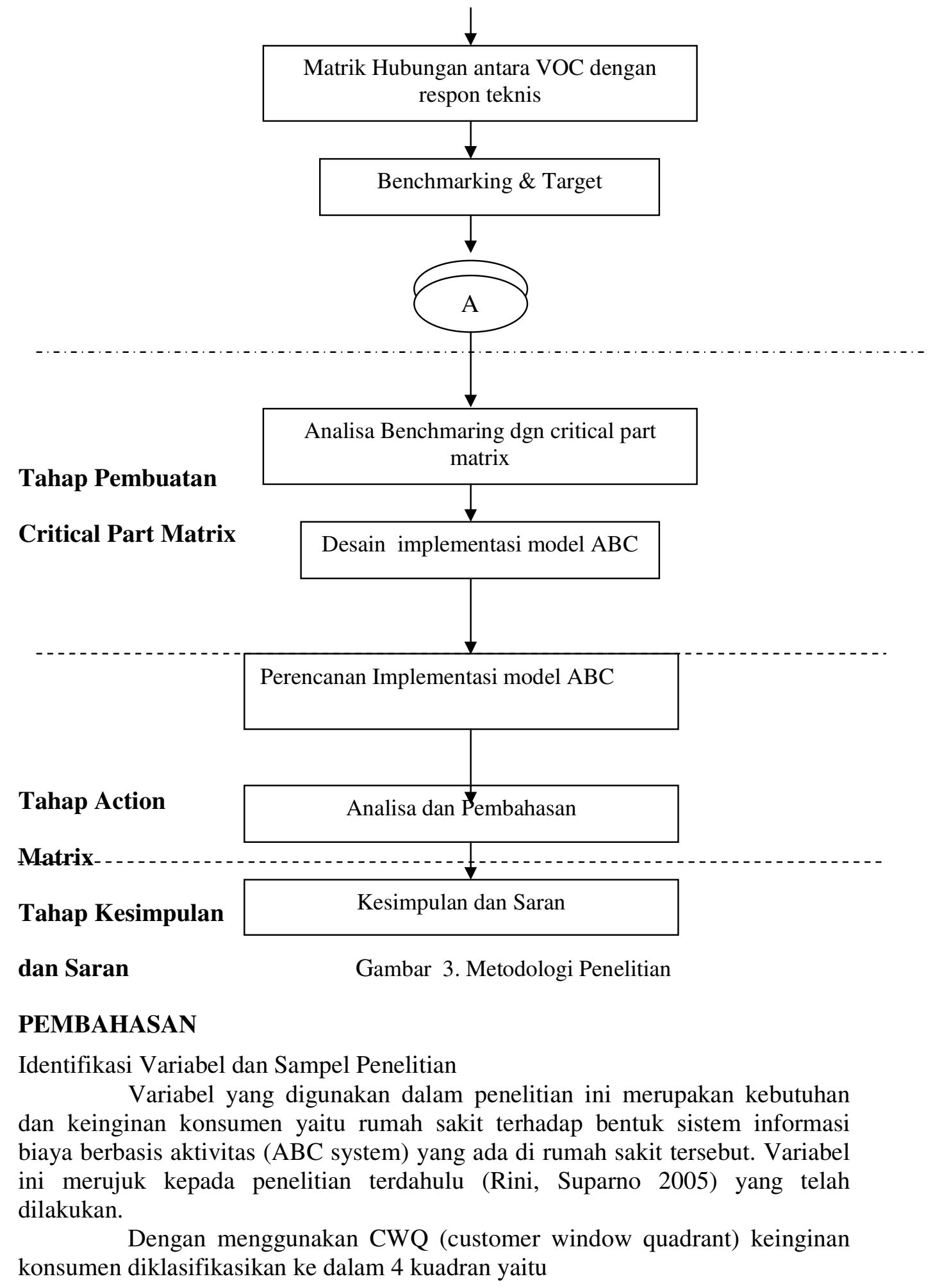


A. Konsumen ingin dan tidak mendapatkan , kebutuhan tinggi/ kepuasan rendah. Jika semua keinginan konseumen terpenuhi maka akan berpindah ke kuadran B

B. Konsumen ingin dan mendapatkan, kebutuhan tinggi/ kepuasan tinggi. Kuadran yang diinginkan dan sebaiknya semua keinginan konsumen berada di kuadran ini.

C. Konsumen tidak menginginkan dan mendapatkan, kebutuhan rendah/ kepuasan tinggi. Diperlukan suatu tindakan untuk menurunkan karakteristik kualitas pada kuadran ini.

D. Konsumen tidak menginginkan dan tidak mendapatkan, kebutuhan rendah/ kepuasan rendah. Tidak memerlukan tindakan apapun untuk saat ini.

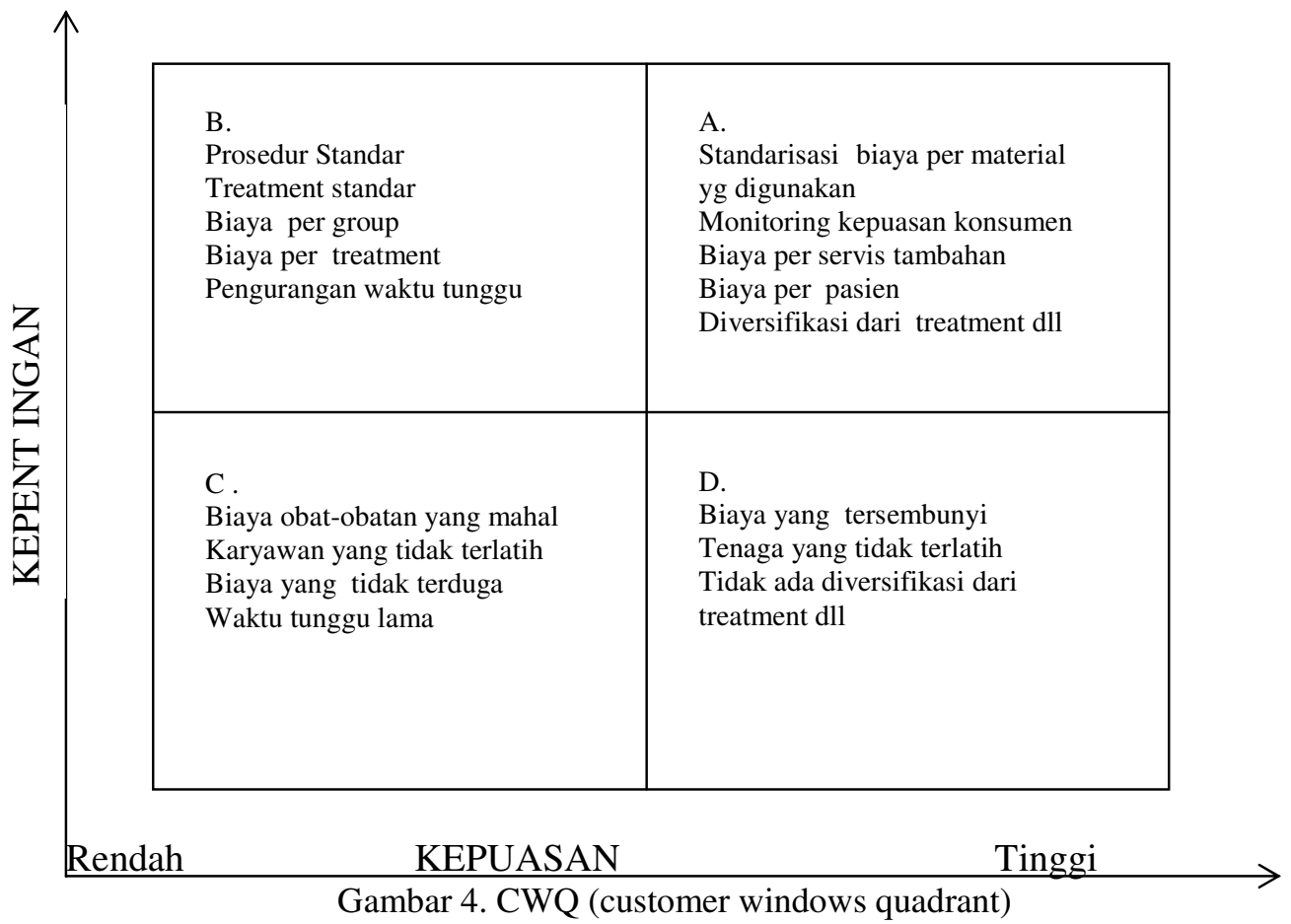

Hasil pengkategorian kebutuhan dan harapan responden tampak dalam tabel 1 berikut ini.

Tabel 1 Atribut Sistem Informasi Biaya berbasis aktivitas di Rumah Sakit

\begin{tabular}{|c|c|c|c|}
\hline No & Atribut & & Uraian \\
\hline \multirow[b]{5}{*}{1} & \multirow[b]{5}{*}{ Administrasi } & 1 & Detail info per pasien \\
\hline & & 2 & Sistem informasi pembiayaan \\
\hline & & 3 & Biaya pelatihan \\
\hline & & 4 & Indirect cost \\
\hline & & 5 & Overhead cost \\
\hline \multirow[b]{3}{*}{2} & \multirow[b]{3}{*}{ Treatment } & 1 & Biaya per group \\
\hline & & 2 & Biaya per gender \\
\hline & & 3 & Biaya per perlakuan \\
\hline
\end{tabular}




\begin{tabular}{|l|l|r|l|}
\hline \multirow{2}{*}{} & \multirow{2}{*}{} & 4 & Biaya per diagnosa \\
\cline { 3 - 4 } & 5 & Biaya per laboratorium \\
\cline { 3 - 4 } & 6 & Biaya resep \\
\hline \multirow{4}{*}{3} & \multirow{3}{*}{ Pelayanan \& ruang } & 1 & Biaya per ruang \\
\cline { 3 - 4 } & & 2 & Biaya material \\
\hline \multirow{3}{*}{4} & \multirow{3}{*}{ Biaya lain-lain } & 3 & Biaya makanan \\
\cline { 3 - 4 } & & 1 & Perlakuan khusus \\
\hline
\end{tabular}

Sebagai responden disini adalah manajer keuangan dan karyawan rumah sakit sebagai pengguna sistem informasi biaya berbasis aktivitas (ABC system).

Pihak direksi rumah sakit akan menjadi responden untuk mengumpulkan data goal dan penyusunan daftar SQC. Kebutuhan dan harapan responden tersebut di atas digunakan sebagai dasar penyusunan kuesioner tertutup untuk mengetahui harapan (tingkat kepentingan) dan tingkat kepuasan responden akan sistem informasi biaya berbasis aktivitas (ABC system) di rumah sakit. Kebutuhan responden selanjutnya akan disebut sebagai atribut dalam proses penyusunan House of Quality.

\section{Improvement Ratio Sistem Informasi biaya berbasis aktivitas}

Nilai ini menunjukkan tingkat kepentingan yang harus dilakukan untuk mencapai target pengembangan dengan mengacu pada tingkat kepuasan atribut jasa pelayanan perusahaan.

Semakin tinggi rasio perbaikan menunjukkan semakin membutuhkan usaha yang tinggi untuk mencapai target. Pada langkah berikutnya informasi ini akan dijadikan masukan dalam menetukan bobot atribut.

$$
\mathrm{IR}=\frac{\text { nilai } t \text { arg } \text { et }(\text { goal })}{\text { tingkat kepuasan pelanggan }}
$$

Tabel 2 Improvement Ratio, Raw Weight, Normalized Raw Weight Sistem Informasi Biaya Berbasis Aktivitas (model ABC) di RS 1

\begin{tabular}{|c|c|c|c|c|c|c|c|}
\hline \multirow{2}{*}{ No } & \multirow{2}{*}{ Atribut } & & \multirow{2}{*}{ Uraian } & \multirow{2}{*}{ Target } & & & \\
\hline & & & & & IR & RW & NRW \\
\hline \multirow[b]{5}{*}{1} & \multirow[b]{5}{*}{ Administrasi } & 1 & $\begin{array}{l}\text { Detail info per } \\
\text { pasien }\end{array}$ & 4.367 & 1.149 & 4.980 & 0.070 \\
\hline & & 2 & $\begin{array}{l}\text { Sistem informasi } \\
\text { pembiayaan }\end{array}$ & 4.333 & 1.000 & 4.000 & 0.056 \\
\hline & & 3 & Biaya pelatihan & 4.367 & 1.057 & 4.438 & 0.062 \\
\hline & & 4 & Indirect cost & 4.400 & 1.065 & 4.719 & 0.066 \\
\hline & & 5 & Overhead cost & 4.333 & 1.048 & 4.578 & 0.064 \\
\hline \multirow[b]{4}{*}{2} & \multirow[b]{4}{*}{ Treatment } & 1 & Biaya per group & 4.333 & 1.130 & 4.824 & 0.068 \\
\hline & & 2 & Biaya per gender & 4.100 & 1.000 & 4.067 & 0.057 \\
\hline & & 3 & Biaya per perlakuan & 4.100 & 1.000 & 4.333 & 0.061 \\
\hline & & 4 & Biaya per diagnosa & 4.200 & 1.050 & 4.375 & 0.061 \\
\hline
\end{tabular}




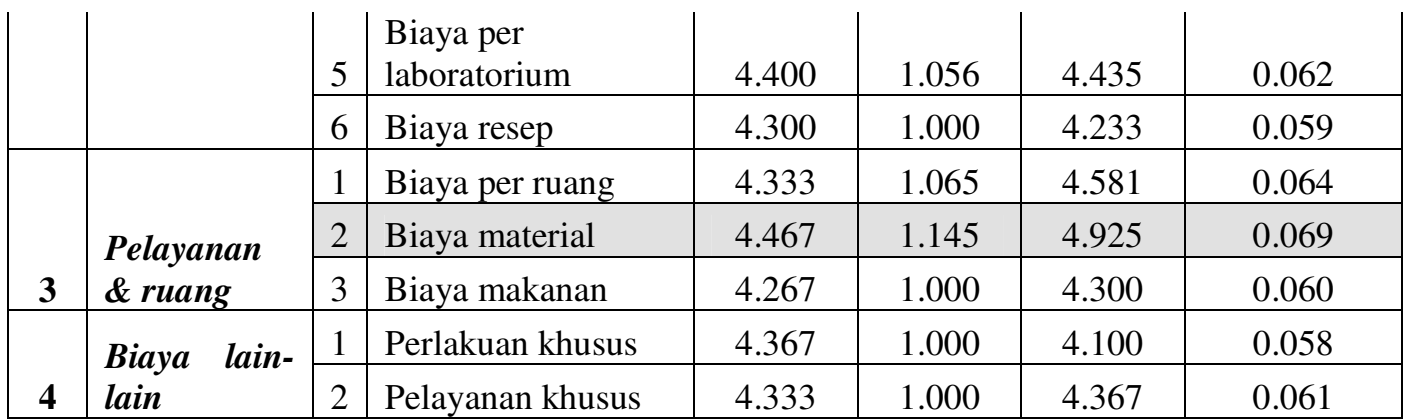

Rasio perbaikan untuk masing-masing atribut menunjukkan bobot kesulitan dalam melakukan peningkatan. Bila nilai rasio perbaikan lebih dari 1 ( satu ) maka perlu diperlukan peningkatan, sedangkan bila nilai rasio perbaikan sebesar 1 ( satu ), maka performansi ( kinerja atribut jasa ) cukup dipertahankan.

Berdasarkan hasil pengolahan data rasio perbaikan menunjukkan bahwa urutan teratas rasio perbaikan yang perlu menjadi perhatian dari perusahaan untuk diperbaiki adalah atribut administrasi dengan dimensi detail info per pasien dengan nilai rasio perbaikan 1.149. Dengan mengetahui besarnya improvement ratio, organisasi dapat mengalokasikan sumber daya yang dimiliki sehingga produk atau jasa yang diproduksi dapat sesuai dengan kebutuhan konsumen.

Seluruh aspek sistem informasi biaya berbasis aktivitas di rumah sakit 1 memerlukan perbaikan yang cukup besar. Namun rumah sakit 1 sebaiknya lebih fokus pada atribut Administrasi, karena atribut Administrasi memiliki tingkat hambatan yang sangat berat dan memerlukan perbaikan yang sangat besar. Lebih spesifik lagi, dimensi yang sangat memerlukan perbaikan adalah dimensi "detail info per pasien". Untuk atribut lain, dimensi yang memerlukan perbaikan adalah dimensi biaya material dan biaya per group.

\section{Raw Weight dan Normalized Raw Weight Sistem Informasi Biaya Berbasis Aktivitas (ABC system)}

Skor Raw Weight sistem informasi biaya berbasis aktivitas (ABC sistem) di RS1 didapat dengan

$$
\begin{aligned}
& R W=I C \times I R \times S P \\
& \mathrm{IC}=\text { Importance to Customer (kepentingan relatif), } \\
& \mathrm{IR}=\text { Improvement Ratio } \\
& \mathrm{SP}=\text { Sales Point } .
\end{aligned}
$$

Skor Sales Point ditentukan sendiri oleh organisasi berdasarkan tingkat kemampuan mereka untuk memenuhi kebutuhan konsumen. Sales point diklasifikasikan dalam tiga kategori yaitu skor 1 (No sales point); skor 1,2 (Medium sales point) dan skor 1,5 (Strong sales point). Pada penelitian ini SP masing-masing atribut tidak mempunyai perbedaan.

\section{Normalisasi Bobot ( Normalized Raw Weight ( NRW ))}


Nilai normalisasi bobot menunjukkan kontribusi atribut terhadap semua keinginan pelanggan. Semakin besar nilai normalisasi bobot maka semakin besar pula kontribusi atribut dalam memenuhi keinginan pelanggan. Nilai normalisasi bobot dapat dihitung dengan rumus :

$$
\mathrm{NRW}=\frac{\text { nilai bobot }(\text { raw weight })}{\text { total nilai bobot }(\text { cumulative raw weight })}
$$

Berdasarkan tabel 2 dapat dipelajari besarnya bobot mentah (raw weight) dan bobot bersih (Normalized Raw Weight). Bobot mentah dan bobot bersih yang terbesar dalam atribut Administrasi, Treatment,Pelayanan dan ruang dan biaya lain-lain adalah sama, yaitu pada dimensi detail info per pasien.

Berdasarkan informasi tersebut di atas dapat disusun suatu prioritas pemenuhan kebutuhan. Prioritas utama dari ketiga atribut yang ada adalah pada atribut Adminitrasi. Hal ini disebabkan karena atribut ini memiliki Cummulative Normalized Raw weight (CNRW) yang paling besar. Sedangkan dimensi yang perlu mendapat perhatian utama dalam atribut ini adalah "detail info per pasien"

Prioritas kedua adalah dalam atribut Pelayanan dan ruang. Dimensi yang perlu mendapat perhatian utama adalah dimensi 'biaya material'. Sedangkan prioritas yang terakhir adalah atribut Treatment, dengan dimensi utamanya adalah " Biaya per group".

\section{Respon Teknis Organisasi (Technical Response)}

Respon teknis organisasi disebut juga Voice of developer. Merupakan bahasa internal atau teknis yang digunakan oleh organisasi untuk menggambarkan apa saja yang diperlukan organisasi dalam menyampaikan produk jasanya untuk memuaskan konsumen. Respon teknis rumah sakit 1 ditetapkan oleh direksi rumah sakit tersebut. Hasil respon teknis tersebut adalah sebagai berikut:

Tabel 3 Respon Teknis dari Sistem Informasi Biaya Berbasis Aktivitas (ABC system)

\begin{tabular}{|c|c|c|c|}
\hline NO & Respon Teknis & & Uraian \\
\hline \multirow[b]{5}{*}{1} & \multirow[b]{5}{*}{ Pendaftaran } & 1 & Biaya registrasi \\
\hline & & 2 & Manajemen basis data \\
\hline & & 3 & Biaya gedung / lahan \\
\hline & & 4 & Biaya lain-lain \\
\hline & & 5 & Indirect cost \\
\hline \multirow[b]{8}{*}{2} & \multirow[b]{8}{*}{ Diagnosa } & 6 & Pengeluaran administrasi \\
\hline & & 7 & Biaya ruang \\
\hline & & 8 & Biaya karyawan ( perawat, teknisi, dll ) \\
\hline & & 9 & Biaya material / bahan ( obat-obatan ) \\
\hline & & 10 & Overhead cost \\
\hline & & 11 & Servis penunjang \\
\hline & & 12 & Analisa lab \\
\hline & & 13 & Biaya pealatan \\
\hline \multirow[b]{4}{*}{3} & \multirow[b]{4}{*}{ Treatment } & 14 & Biaya ruang \\
\hline & & 15 & Biaya karyawan \\
\hline & & 16 & Biaya material / bahan \\
\hline & & 17 & Overhead cost \\
\hline
\end{tabular}




\begin{tabular}{|l|l|l|l|}
\multirow{2}{*}{} & 18 & Servis penunjang \\
\cline { 3 - 4 } & 19 & Pelayanan lab \\
\cline { 3 - 4 } & 20 & Biaya penggunaan peralatan \\
\hline \multirow{3}{*}{4} & Lain-lain & 21 & Biaya makanan \\
\cline { 3 - 4 } & & 22 & Biaya perlakuan khusus \\
\hline
\end{tabular}

\section{Penyusunan House of Quality}

Setelah selesai menyusun Planning matrix dan menetapkan technical response, maka penyusunan House of Quality dilanjutkan dengan menyusun matriks relationship dengan cara menetapkan kuat hubungan antara customer need dengan technical response. Proses penyusunannya dipaparkan berikut ini.

\section{Penentuan Kuat Hubungan antara Technical Response dengan Customer} Need

Sebelum menganalisis hubungan (relationship) antara kebutuhan dan harapan konsumen (Customer Need) dan respon teknis organisasi (Technical Response) perlu dilakukan penentuan keeratan hubungan antara masing-masing dimensi harapan dengan setiap respon teknis yang ada. Penentuan hubungan dilakukan dengan

nilai 1 = untuk hubungan lemah

nilai 3 = untuk hubungan sedang

nilai 9 = untuk hubungan yang kuat.

Nilai $0=$ tidak ada hubungan

Penentuan kekuatan hubungan ini dilakukan oleh tim di Rumah Sakit, dalam hal ini adalah direksi dan manajer keuangan.

\section{Penentuan Prioritas dari Technical Response (SQC)}

Matriks ini menjabarkan kontribusi relatif dari Technical Response terhadap kepuasan pelanggan (Customer Satisfaction) secara keseluruhan menggambarkan prioritas dari Technical Response. Perhitungan matematis dalam tiap sel matriks ini berdasarkan rumus:

Prioritas $=($ Numerical value dalam Relationship $) \times($ Normalized Raw Weight Need )

Nilai dari perhitungan di atas menggambarkan hubungan pada Technical Response X terhadap Customer Satisfaction pada need A.

Setelah menyelesaikan perhitungan di atas, dilakukan perhitungan Normalized Relationship dengan rumus sebagai berikut :

Normalized Relationship $=\underline{\text { Relationship A }}$

Total Relationship

Angka perhitungan yang paling besar merupakan technical response yang paling penting (priorities) sehingga technical response ini dapat disimpulkan memiliki pengaruh yang terbesar bagi kepuasan pelanggan. Semakin besar nilai prioritas maka semakin besar pula kontribusi respon teknis tersebut dalam memenuhi kepuasan konsumen.

Tabel 4.Tabel Nilai Prioritas dari Respon Teknis pada sistem informasi biaya berbasis aktivitas (ABC sistem) .

\begin{tabular}{|c|c|c|c|c|}
\hline $\begin{array}{c}\text { Respon } \\
\text { Teknis }\end{array}$ & Uraian & Prioritas & $\begin{array}{c}\text { Kontribusi } \\
\text { ternormalisasi }\end{array}$ & $\begin{array}{c}\text { Urutan } \\
\text { Prioritas }\end{array}$ \\
\hline Pendaftaran & Biaya registrasi & 0.637 & 1.362 & 20 \\
\cline { 2 - 5 }
\end{tabular}




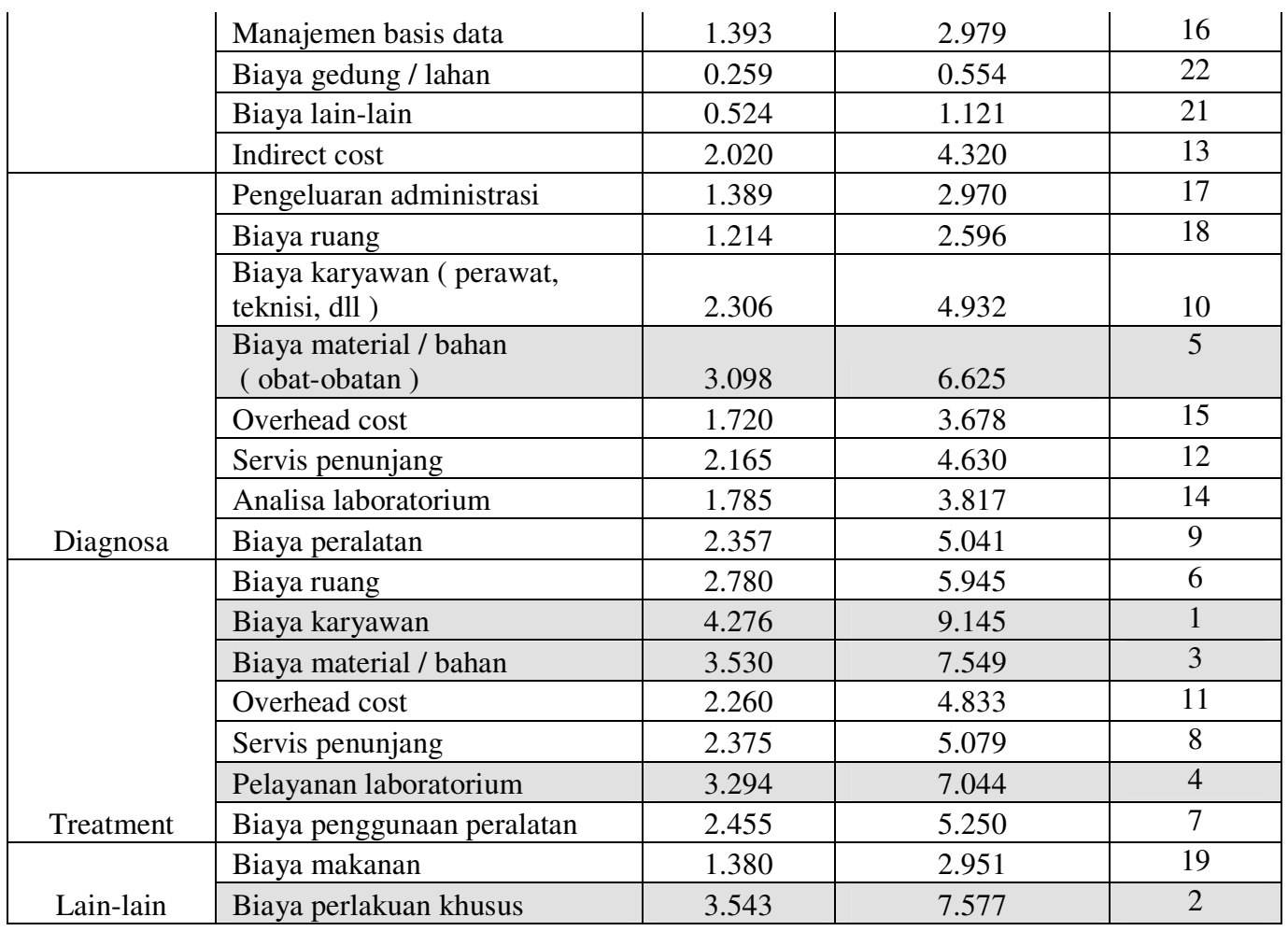

Berdasarkan tabel 4 diperoleh informasi bahwa technical response yang memiliki hubungan (relationship) yang terbesar adalah respon teknis biaya karyawan, biaya perlakuan khusus, biaya material/ bahan, pelayanan laboratorium dan biaya material untuk treatment. Technical response ini disebut Prioritazion of technical response, yang berarti respon teknis yang menjadi prioritas dan memiliki sensitivitas tinggi terhadap kualitas sistem informasi biaya berbasis aktivitas. Setelah melalui berbagai perhitungan dalam Planning Matrix yang dianalogikan sebagai pilar dan matriks Relationship yang dianalogikan sebagai dasar, maka dapat disusunlah sebuah rumah kualitas sebagai suatu bangunan yang utuh.

\section{Benchmarking}

Dilakukan perbandingan antara keinginan konsumen dari rumah sakit 1 dengan rumah sakit lainnya.

\section{Rencana Perbaikan Sistem Informasi Biaya Berbasis Aktivitas (ABC sistem)}

Berdasarkan hasil analisa dari rumah kualitas maka dengan menggunakan metode brainwriting dan brainstorming dengan tim yang terdiri dari direksi dan orang-orang yang mempunyai pengetahuam dan keahlian di bidang ini maka dibuat rencana perbaikan seperti tampak pada tabel sebagai berikut: 
Tabel 5. RENCANA PERBAIKAN

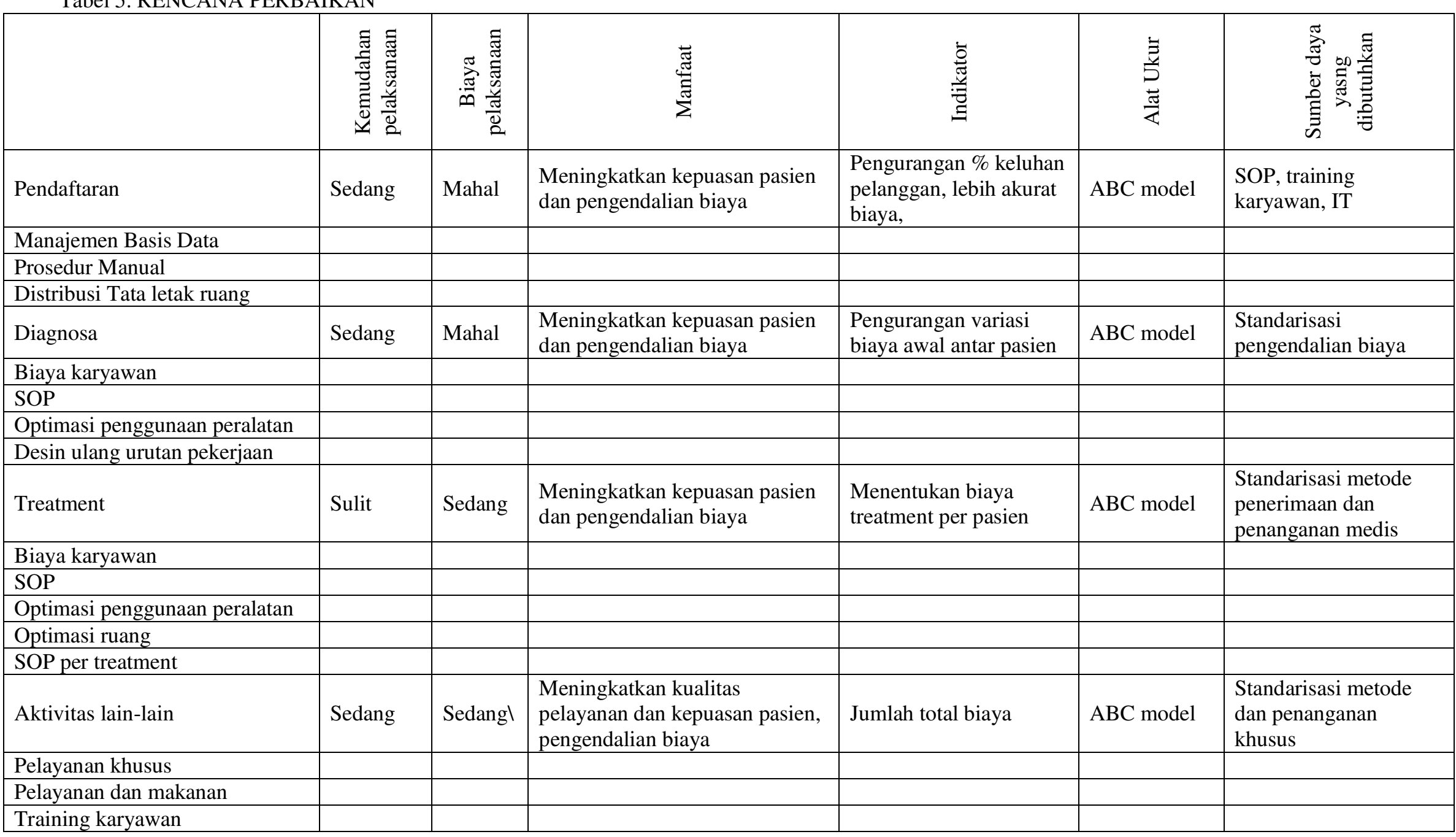




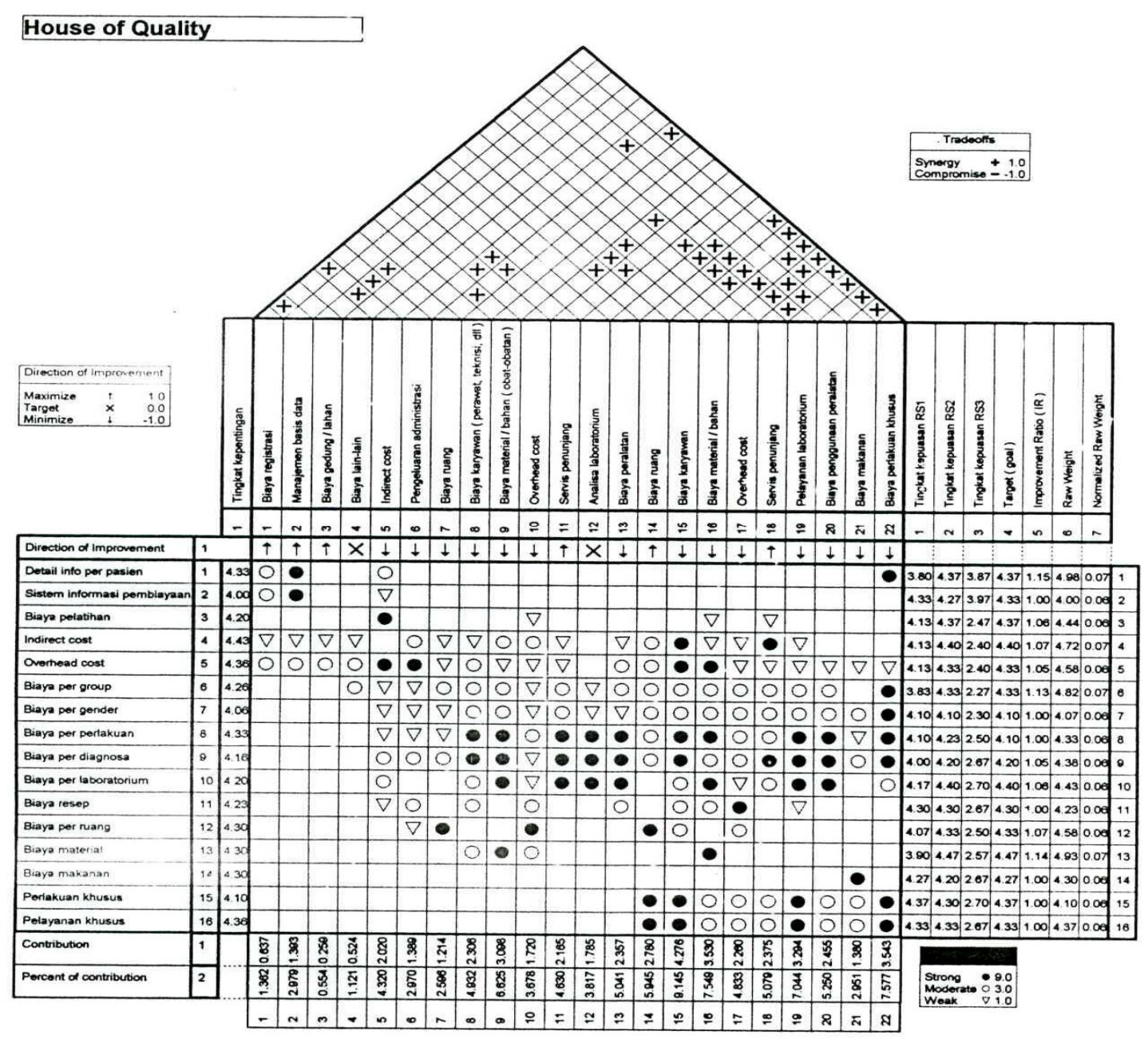




\section{KESIMPULAN}

Berdasarkan analisis hasil penelitian dan pembahasan, maka dapat disimpulkan beberapa hal adalah sebagai berikut:

1. Analisis terhadap sistem informasi biaya berbasis aktivitas (ABC sistem) menunjukkan bahwa harapan pelanggan (rumah sakit dan manajer keuangan) tertinggi adalah atribut administrasi pada dimensi detail info per pasien. Namun di sisi lain dimensi ini mempunyai kepuasan yang terrendah. Oleh karena itu kedua dimensi ini memiliki gap yang terbesar. Dimensi 'detail info per pasien yang terbesar dan menjadi prioritas pertama dari Customer need.

2. Respon teknis organisasi yang dapat menjawab prioritas kebutuhan dan harapan pelanggan secara keseluruhan adalah biaya karyawan, biaya perlakuan khusus, biaya material/ bahan, pelayanan laboratorium dan biaya material untuk treatment.

3. Bila dibandingkan dengan kompetitor maka dimensi detail info per pasien, biaya material, biaya per group memiliki tingkat kepuasan paling rendah.

4. Rencana perbaikan dari hasil QFD yang sudah dilakukan dan berdasarkan hasil brainstorming dengan tim yang mempunyai keahlian di bidangnya dapat dilihat pada tabel 5

\section{DAFTAR PUSTAKA}

1. Akao, Y. ,1990, "Quality Functon Deployment", Productivity Press, Cambridge, MA,.

2. Gonzales,M. 2001, "Quality Function Deployment; A Road for Listening the Customer Expectations", McGraw-Hill, Mexico.

3. Hemmasi, M., Strong, K., Taylor,S 1994, "Measuring service quality for strategic planning and analysis in ervice firms", Journal of Applied Bussiness Research, Vol.10 No4, pp 24-34.

4. Hauser , J.R., Clausing,D., 1988, "The house of Quality", Harvard Business Review, May-June, pp.36-44.

5. Intel Corporation , 1997, " Customer window quadrant", Technical Report, Intel Corporation, Dan Jose, CA, pp 45-58.

6. Lamberth, Don and John Afflect Graves, 1996, "How ABC ac Help Service Organization”, CMA Management, ABI/INFORM Research, hal 24 - 28.

7. Magia, Adam S and Fred A Jacobs, 2003, "Balanced Score Card, Activity Based Costing and Company Performance: An Empirical Analysis, Journal of Managerial Issues, ABI/INFORM Research, hal $24-28$.

8. Parasuraman, A., Berry L.L, \& Zeitham. V,A., 1990, "Delivery Quality Service: Balancing Customer Perseption And Expextations", The Free Press, A Division of Macmillan. Inc.

9. Priyo Hari Adi, 2005, Implementasi Activity Based Costing terhadap kinerja perusahaan, Jurnal Ekonomi dan Bisnis, hal 101-118.

10. Reimann, BernardC, 1990, "The ABC of Accounting of Value Creation", ABI/INFORM Research, hal 33 - 34.

11. Tunggal, Amin Widjaja, 2000, “Activity Based Costing, Havarindo, Jakarta.

12. Urrutia de Hoyos, I, 2002, "Implementation of an ABC Model in Hospitals, Communidad de Madrid, Madrid. 